\title{
The antioxidant activity of ethanolic and aqueous extracts of dandelion (Taraxacum officinale L.)
}

\author{
Aktywność antyoksydacyjna wyciągów etanolowych i wodnych z mniszka lekarskiego \\ (Taraxacum officinale L.)
}

\author{
Anna Nowak ${ }^{1 凶}$, Wiktoria Duchnik¹, Joanna Zielonka-Brzezicka1', Anna Muzykiewicz¹, Katarzyna Florkowska', \\ Adam Klimowicz', Łukasz Kucharski', Daria Wysocka², Agnieszka Dziedzic² \\ ${ }^{1}$ Pomorski Uniwersytet Medyczny w Szczecinie, Katedra i Zakład Chemii Kosmetycznej i Farmaceutycznej, al. Powstańców Wlkp. 72, 70-111 Szczecin \\ Pomeranian Medical University in Szczecin, Department of Cosmetic and Pharmaceutical Chemistry \\ ${ }_{2}^{2}$ Pomorski Uniwersytet Medyczny w Szczecinie, Studenckie Koło Naukowe przy Katedrze i Zakładzie Chemii Kosmetycznej i Farmaceutycznej, al. Powstańców Wlkp. \\ 72, 70-111 Szczecin \\ Pomeranian Medical University in Szczecin, Student Science Club at the Department of Cosmetic and Pharmaceutical Chemistry \\ $\triangle$ anowak@pum.edu.pl
}

\begin{abstract}
Introduction: Dandelion (Taraxacum officinale L.) has been commonly used in traditional and contemporary medicine due to its diuretic and hepatoprotective properties. It contains polyphenols, vitamins and terpenes - i.e. compounds with antioxidant potential. Natural antioxidants protect organisms against oxidative stress, an important factor in the ageing process and in the pathogenesis of neoplastic, cardiovascular, neurodegenerative and some other diseases.

Materials and methods: Raw dandelion plant material consisted of fresh and dried leaves, flowers and roots, harvested from a natural site. The extracts for analysis were prepared using an ultrasonic bath (extraction time 15, 30 and $60 \mathrm{~min}$ ) in water, and $40 \%(\mathrm{v} / \mathrm{v}), 70 \%(\mathrm{v} / \mathrm{v})$ and $96 \%(\mathrm{v} / \mathrm{v})$ ethanol mixtures used as solvents. Antioxidant activity was evaluated using
\end{abstract}

2,2-diphenyl-1-picrylhydrazyl (DPPH) and ferric reducing antioxidant power (FRAP) methods.

Results: The antioxidant activity of dandelion depended on the type of raw material used, as well as the type of solvent and extraction time. The highest DPPH activity was found for dried flower extracts prepared in $70 \%$ ethanol for $30 \mathrm{~min}$. With FRAP method, the highest reduction capacity was observed for dried leaf extracts in $40 \%$ ethanol for $30 \mathrm{~min}$.

Conclusions: The antioxidant potential of ethanolic and aqueous dandelion extracts was observed. This finding suggests the usefulness of this plant as a source of antioxidants to be used in pharmaceutical and cosmetic industries.

Keywords: dandelion; antioxidant activity; DPPH; FRAP; ultrasound-assisted extraction; ethanolic extracts; aqueous extracts.

\begin{abstract}
ABSTRAKT
Wstęp: Mniszek lekarski (Taraxacum officinale L.) znalazł zastosowanie zarówno w ludowej, jak i współczesnej medycynie jako surowiec moczopędny oraz działający ochronnie na miąższ wątroby. Zawiera on m.in. polifenole, witaminy i terpeny, które wykazują działanie przeciwutleniające. Substancje będące naturalnymi antyoksydantami chronią organizm przed stresem oksydacyjnym, odgrywającym istotną rolę w procesie starzenia oraz patogenezie nowotworów, choroby wieńcowej czy chorób neurodegeneracyjnych.

Materiały i metody: Materiał roślinny stanowiły świeże i suszone liście, kwiaty oraz korzenie mniszka lekarskiego zebrane ze stanowiska naturalnego. Wyciągi sporządzono metodą ekstrakcji wspomaganej ultradźwiękami, trwającej 15, 30 oraz 60 min, przy czym jako rozpuszczalniki zastosowano $40 \%$ (v/v), 70\% (v/v) i 96\% (v/v) etanol oraz wodę. Aktywność antyoksydacyjną oznaczano metodami 2,2-difenylo-1-pikrylohydrazylu
\end{abstract}

(DPPH) oraz oznaczania zdolności redukowania jonów żelaza (FRAP).

Wyniki: Działanie przeciwutleniające mniszka lekarskiego było zależne od użytego surowca, zastosowanego rozpuszczalnika, a także czasu ekstrakcji. W przypadku metody DPPH najwyższą aktywność wykazywały wyciągi z suszonych kwiatów przygotowane w 70\% etanolu (czas ekstrakcji - $30 \mathrm{~min}$ ). Przy zastosowaniu metody FRAP najwyższe działanie przeciwutleniające zaobserwowano dla wyciągów z suchych liści przygotowanych $\mathrm{w}$ alkoholu $40 \%$ (czas ekstrakcji - $30 \mathrm{~min}$ ).

Wnioski: Etanolowe i wodne wyciągi z mniszka lekarskiego wykazują działanie antyoksydacyjne. Może to sugerować ich przydatność w przemyśle kosmetycznym i farmaceutycznym. Słowa kluczowe: mniszek lekarski; aktywność antyoksydacyjna; DPPH; FRAP; ekstrakcja wspomagana ultradźwiękami; ekstrakty etanolowe; ekstrakty wodne.

\section{INTRODUCTION}

Dandelion (Taraxacum officinale L.) is a perennial plant belonging to the Asteraceae family. It is deeply rooted, meaning that even after cutting the aerial parts, it is able to regenerate new growth. A typical specimen of dandelion contains 5-10 flowers

that transform into seeds containing hairy down fluff to allow dispersal by the wind. Due to the content of biologically active ingredients in the leaves, flowers and roots, its traditional use has been documented in many countries [1]. The largest crops of dandelion in Europe can be found in Poland, Bulgaria, Romania and Hungary. Moreover, it can be often found 
as a wild growing weed, highly resistant to adverse weather conditions. It is estimated that in moderate regions there are about 2,800 varieties of this plant [2]. Dandelion, both in its raw and processed form, is well tolerated by humans and practically no adverse effects can be observed after its use. In some countries, its leaves are consumed in raw form as ingredients in salads, while roasted root can be applied as a substitute for coffee [3]. Biologically active compounds have been found in various parts of this plant. The roots are rich in phenolic and terpene compounds, sesquiterpene lactones, fructosans and inulin. The leaves contain substances belonging to the group of flavonoids, phenolic acids, coumarins and vitamins, especially vitamin A [4]. The flowers are rich in active compounds, including caffeic acid, chlorogenic acid, as well as luteolin derivatives [2]. Numerous studies confirm a number of pro-health properties of the dandelion. Due to the content of the mentioned chlorogenic acid and taraxasterols or sesquiterpene lactones, dandelion has a beneficial effect in the treatment of humans suffering from type 2 diabetes [2]. Moreover, its anti-inflammatory and antioxidant effects are also confirmed, as well as immunostimulating, antiallergic or diuretic properties [5, 6]. Its beneficial health-promoting effect on the gastrointestinal tract and metabolism is well known both in humans and animals $[7,8]$. In addition, many reports on the antioxidant activity of extracts from various parts of Taraxacum officinale can be found. This activity is mainly due to the presence of phenolic compounds, especially flavonoids $[5,9]$. The content of compounds with a radical scavenging activity is important due to their possibility to decrease so called oxidative stress, which is responsible for a number of adverse effects on living organisms, for instance Parkinson's and Alzheimer's diseases as well as cardiovascular and neoplastic disorders [10, 11]. In addition, oxidative stress is a significant factor in the development of metabolic diseases, among others, diabetes [12], as well as certain mental disorders [13].

The aim of the study was to evaluate and to compare the antioxidant activity of extracts, alcoholic and aqueous, of fresh and dried parts of the dandelion, such as the flower, leaf and root, harvested while the plant is flowering.

\section{MATERIALS AND METHODS}

2,4,6-tripyridyl-S-triazine (TPTZ), 2,2-diphenyl-1-picrylhydrazyl (DPPH) and 6-hydroxy-2,5,7,8-tetramethylchroman-2-carboxylic acid (trolox) were purchased from Sigma Aldrich, USA; iron (III) chloride hexahydrate and iron (VI) sulphate (II) heptahydrate from Merck, Darmstadt, Germany; glacial acetic acid, anhydrous sodium acetate, $36 \%$ hydrochloric acid (all of analytical purity) and ethyl alcohol - from Chempur, Piekary Śląskie.

The dandelion was harvested from a natural location close to Szczecin. The leaves, flowers and root of the plant were used to obtain extracts in $40 \%(\mathrm{v} / \mathrm{v}), 70 \%$ (v/v), $96 \%$ (v/v) ethanol to water baths. To prepare the extracts, $5 \%$ of plant raw material was added to each of the 3 solvent baths, followed by ultrasound-assisted extraction for 15, 30 or 60 min.
The antioxidant activity was assessed using DPPH and ferric reducing antioxidant power (FRAP) methods, as previously described $[14,15,16]$.

Statistical analysis of the results was performed using oneway analysis of ANOVA variance, with a significance level $\alpha=$ 0.05. Inter-group differences were determined by Tukey test $(n=3)$. The Pearson correlation coefficient between the antioxidant activity determined by the DPPH and FRAP method, was calculated in mg trolox/g of raw material for particular parts of the plant. All the calculations were performed in Statistica 12 (StatSoft).

\section{RESULTS}

Tables 1 and 2 present the antioxidant activities of the extracts, taking into account the part of the plant used to obtain the extract as well as the extraction time and the solvent applied. In Figure 1, the vertical lines represent standard deviation (SD), and the bars marked with different letters differ significantly within the part of the plant (significance level: $\alpha=0.05 ; n=3$ ).

The antioxidant potential of the evaluated samples ranged from $0.010 \pm 0.003$ to $3.37 \pm 0.01 \mathrm{mg}$ trolox/g of raw material, and corresponded to values from $1.87 \pm 0.08 \%$ to $72.52 \pm 0.25 \%$ RSA (radical scavenging activity). The highest activity was found for the extract of dried dandelion flowers, extracted in 70\% ethanol for $30 \mathrm{~min}$. A high activity was also observed for the extracts of dried leaves in the same solvent - from $2.80 \pm 0.04$ to 3.18 $\pm 0.04 \mathrm{mg}$ trolox/g of raw material. Taking into account the type of raw material evaluated, in the majority of cases, higher values were obtained for the extracts of dried leaves, flowers and roots compared to their fresh form. The root was characterized by a lower activity than the other parts of the plant, the mean was $23.13 \%$ RSA, while for the leaf-35.22\% RSA, and the flower $-30.16 \%$ RSA. The lowest DPPH radical scavenging capacity was found for the aqueous fresh leaves extracted for $30 \mathrm{~min}$ (0.011 $\pm 0.002 \mathrm{mg}$ trolox/g of raw material) and for $15 \mathrm{~min}(0.05 \pm 0.03$ $\mathrm{mg}$ trolox/g of raw material), and corresponded to $1.87 \pm 0.08 \%$ and $2.67 \pm 0.67 \%$ RSA, respectively. The antioxidant activities of leaf and flower extracts prepared in water are usually much lower than the ethanol extracts (Tab. 1, Fig. 1).

The iron ion reduction capacities, determined by the FRAP method and expressed as trolox equivalents (mg trolox/g of raw material) are summarized in Table 2.

The reduction capacity varied between $0.79 \pm 0.02$ and 28.92 $\pm 0.27 \mathrm{mg}$ trolox/g of raw material. The highest activities were observed for the extracts of dried leaves prepared in $40 \%$ ethanol - $25.18 \pm 0.3915 \mathrm{~min} ; 28.92 \pm 0.2730 \mathrm{~min} ; 27.63 \pm 0.95 \mathrm{mg}$ trolox/g of raw material $60 \mathrm{~min}$. Similar to the previous method, the reduction capacity of the extracts of dried dandelion leaf were higher than the other parts of the plant - on average $10.04 \mathrm{mg}$ trolox/g of raw material, versus the flower $-3.79 \mathrm{mg}$ trolox/g of raw material and only $2.75 \mathrm{mg}$ trolox/g of raw material for the root. High reduction properties were also found for extracts obtained from dried flowers, between $1.73 \pm 0.15$ and $10.13 \pm 0.13 \mathrm{mg}$ trolox/g of raw material. The lowest antioxidant 
TABLE 1. Mean ( \pm SD) antioxidant activity of ethanolic and aqueous extracts of roots, flowers and dandelion leaves, determined by DPPH technique and expressed as trolox equivalents ( $\mathrm{mg}$ trolox/g of raw material)

Trolox equivalent ( $\mathrm{mg}$ trolox/g raw material)

\begin{tabular}{|c|c|c|c|c|c|}
\hline \multirow{2}{*}{\multicolumn{2}{|c|}{ Raw material }} & \multirow{3}{*}{ Solvent } & \\
\hline & & & \multicolumn{3}{|c|}{ duration of ultrasound-assisted extraction (min) } \\
\hline & & & 15 & 30 & 60 \\
\hline \multirow{8}{*}{ Flower } & \multirow{4}{*}{ fresh } & ethanol $40 \%(v / v)$ & $2.53 \pm 0.03 \mathrm{~d}$ & $1.36 \pm 0.02 \mathrm{~d}$ & $1.41 \pm 0.03 \mathrm{~d}$ \\
\hline & & ethanol 70\% (v/v) & $1.00 \pm 0.06 \mathrm{c}$ & $0.43 \pm 0.01 \mathrm{~b}$ & $1.10 \pm 0.01 \mathrm{c}$ \\
\hline & & ethanol 96\% (v/v) & $0.80 \pm 0.04 \mathrm{~b}$ & $0.59 \pm 0.06 \mathrm{c}$ & $0.67 \pm 0.07 \mathrm{~b}$ \\
\hline & & water & $0.16 \pm 0.01 \mathrm{a}$ & $0.14 \pm 0.03 \mathrm{a}$ & $0.12 \pm 0.03 \mathrm{a}$ \\
\hline & \multirow{4}{*}{ dried } & ethanol 40\% (v/v) & $2.85 \pm 0.03 \mathrm{c}$ & $2.91 \pm 0.02 \mathrm{c}$ & $1.74 \pm 0.08 b$ \\
\hline & & ethanol 70\% (v/v) & $2.23 \pm 0.02 c$ & $3.37 \pm 0.01 \mathrm{~d}$ & $1.67 \pm 0.02 b$ \\
\hline & & ethanol 96\% (v/v) & $1.58 \pm 0.05 \mathrm{~b}$ & $2.22 \pm 0.03 \mathrm{~b}$ & $1.40 \pm 0.09 \mathrm{~b}$ \\
\hline & & water & $0.62 \pm 0.05 \mathrm{a}$ & $0.74 \pm 0.07 \mathrm{a}$ & $0.92 \pm 0.05 \mathrm{a}$ \\
\hline \multirow{8}{*}{ Leaf } & \multirow{4}{*}{ fresh } & ethanol 40\% (v/v) & $2.74 \pm 0.02 \mathrm{c}$ & $1.64 \pm 0.03 \mathrm{c}$ & $2.91 \pm 0.04 \mathrm{~d}$ \\
\hline & & ethanol 70\% (v/v) & $1.71 \pm 0.09 \mathrm{~b}$ & $1.93 \pm 0.05 \mathrm{~d}$ & $2.01 \pm 0.10 \mathrm{c}$ \\
\hline & & ethanol 96\% (v/v) & $1.70 \pm 0.07 \mathrm{~b}$ & $0.58 \pm 0.04 \mathrm{~b}$ & $0.93 \pm 0.05 b$ \\
\hline & & water & $0.05 \pm 0.03 \mathrm{a}$ & $0.01 \pm 0.00 \mathrm{a}$ & $0.20 \pm 0.01 \mathrm{a}$ \\
\hline & \multirow{4}{*}{ dried } & ethanol $40 \%(v / v)$ & $2.68 \pm 0.07 c$ & $2.47 \pm 0.04 \mathrm{c}$ & $2.71 \pm 0.03 c$ \\
\hline & & ethanol 70\% (v/v) & $2.85 \pm 0.04 \mathrm{C}$ & $2.80 \pm 0.04 \mathrm{~b}$ & $3.18 \pm 0.04 \mathrm{C}$ \\
\hline & & ethanol 96\% (v/v) & $0.79 \pm 0.03 \mathrm{a}$ & $0.74 \pm 0.02 \mathrm{~b}$ & $0.60 \pm 0.05 b$ \\
\hline & & water & $2.45 \pm 0.08 \mathrm{~b}$ & $0.20 \pm 0.02 \mathrm{a}$ & $0.44 \pm 0.06 \mathrm{a}$ \\
\hline \multirow{8}{*}{ Root } & \multirow{4}{*}{ fresh } & ethanol 40\% (v/v) & $0.57 \pm 0.06 \mathrm{a}$ & $0.20 \pm 0.03 \mathrm{a}$ & $0.58 \pm 0.08 b$ \\
\hline & & ethanol 70\% (v/v) & $0.70 \pm 0.07 \mathrm{a}$ & $1.58 \pm 0.03 \mathrm{~d}$ & $0.35 \pm 0.03 \mathrm{a}$ \\
\hline & & ethanol 96\% (v/v) & $0.99 \pm 0.12 \mathrm{~b}$ & $0.40 \pm 0.05 b$ & $0.41 \pm 0.08 \mathrm{a}$ \\
\hline & & water & $1.06 \pm 0.03 \mathrm{~b}$ & $0.83 \pm 0.02 \mathrm{c}$ & $0.32 \pm 0.04 \mathrm{a}$ \\
\hline & \multirow{4}{*}{ dried } & ethanol 40\% (v/v) & $0.72 \pm 0.05 \mathrm{a}$ & $1.91 \pm 0.03 \mathrm{C}$ & $1.91 \pm 0.03 \mathrm{~d}$ \\
\hline & & ethanol 70\% (v/v) & $0.65 \pm 0.08 \mathrm{a}$ & $1.46 \pm 0.03 \mathrm{~b}$ & $1.33 \pm 0.06 \mathrm{c}$ \\
\hline & & ethanol 96\% (v/v) & $0.62 \pm 0.02 \mathrm{a}$ & $0.60 \pm 0.03 \mathrm{a}$ & $1.03 \pm 0.08 \mathrm{~b}$ \\
\hline & & water & $0.95 \pm 0.05 \mathrm{~b}$ & $2.39 \pm 0.02 \mathrm{~d}$ & $0.21 \pm 0.01 \mathrm{a}$ \\
\hline
\end{tabular}

Mean values marked with different letters differ significantly within the applied solvent for extraction (significance level: $\alpha=0.05 ; \mathrm{n}=3$ )
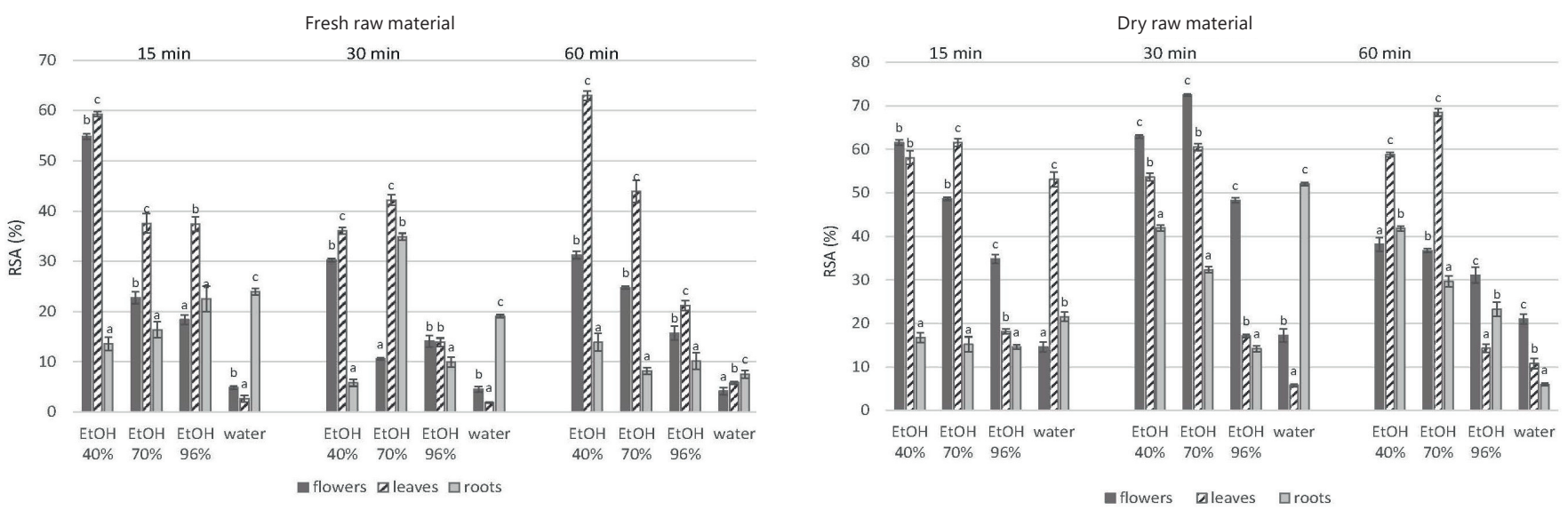

The vertical lines represent standard deviation (SD). Bars marked with different letters differ significantly within a part of the plant (significance level: $\alpha=0.05 ; \mathrm{n}=3$ )

FIGURE 1. Mean \pm standard deviation (SD) antioxidant activity of aqueous and ethanolic (EtOH) extracts of fresh and dried dandelion parts, extracted for 15 , 30 or 60 min, determined by DPPH method and expressed as \%RSA 
TABLE 2. Mean \pm standard deviation (SD) of $\mathrm{Fe}^{3+}$ ion reduction capacity of ethanolic and aqueous extracts of roots, flowers and dandelion leaves, determined by FRAP technique and expressed as trolox equivalents ( $\mathrm{mg}$ trolox/g of raw material)

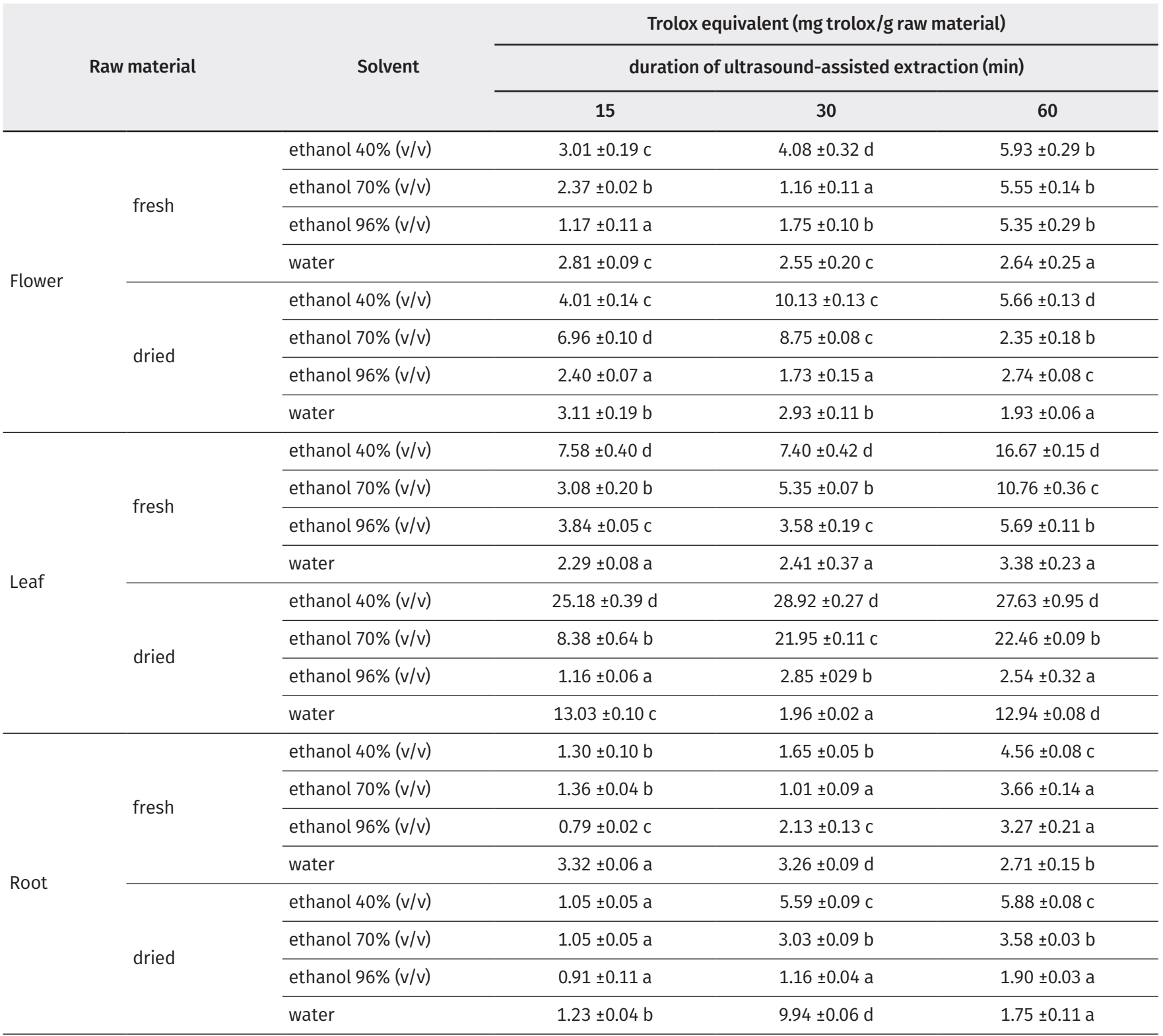

Mean values marked with different letters differ significantly within the applied solvent for extraction (significance level: $\alpha=0.05 ; \mathrm{n}=3$ )

activity, measured by the FRAP method, was found for dried root extracts prepared in $96 \%$ ethyl alcohol for $15 \mathrm{~min}-0.79$ $\pm 0.02 \mathrm{mg}$ trolox/g of raw material and $0.91 \pm 0.11 \mathrm{mg}$ trolox/g of raw material for fresh root extracts. The activity of the aqueous extract of the dried root of $9.94 \pm 0.06 \mathrm{mg}$ trolox/g of raw material, extracted for $30 \mathrm{~min}$, was significantly higher compared to the extracts of this part of dandelion prepared in other solvents (Tab. 2).

Figure 2 presents the relationship between the results obtained by both methods used to evaluate the antioxidant activity for extracts of individual parts of the plant. A statistically significant relationship was found between the activities determined with both methods, the Pearson correlation coefficients were $r=0.726(p<0.0001), r=0.610(p<0.002)$ and $r=0.656(p<0.001)$ for leaf, flower and root extracts, respectively.

\section{DISCUSSION}

In the present study the antioxidant properties of alcoholic and aqueous extracts of various parts of the dandelion, harvested during flowering, were determined. To prepare Taraxacum officinalis extracts, ultrasound-assisted extraction for 15,30 or 60 min was applied using ethanol at 3 concentrations $-40 \%, 70 \%$, $96 \%(\mathrm{v} / \mathrm{v})$ and water as extractants. The dandelion is a plant with antioxidative capacity, however, the obtained results prove that this activity differed depending on several factors including the plant part, the solvent used, as well as the duration of extraction (Tab. 1 and 2). Moreover, the drying process of the raw material could also influence the results. The highest antiradical activity, measured by the DPPH method, was demonstrated by extracts from dried dandelion flowers made in $70 \%$ ethanol for 

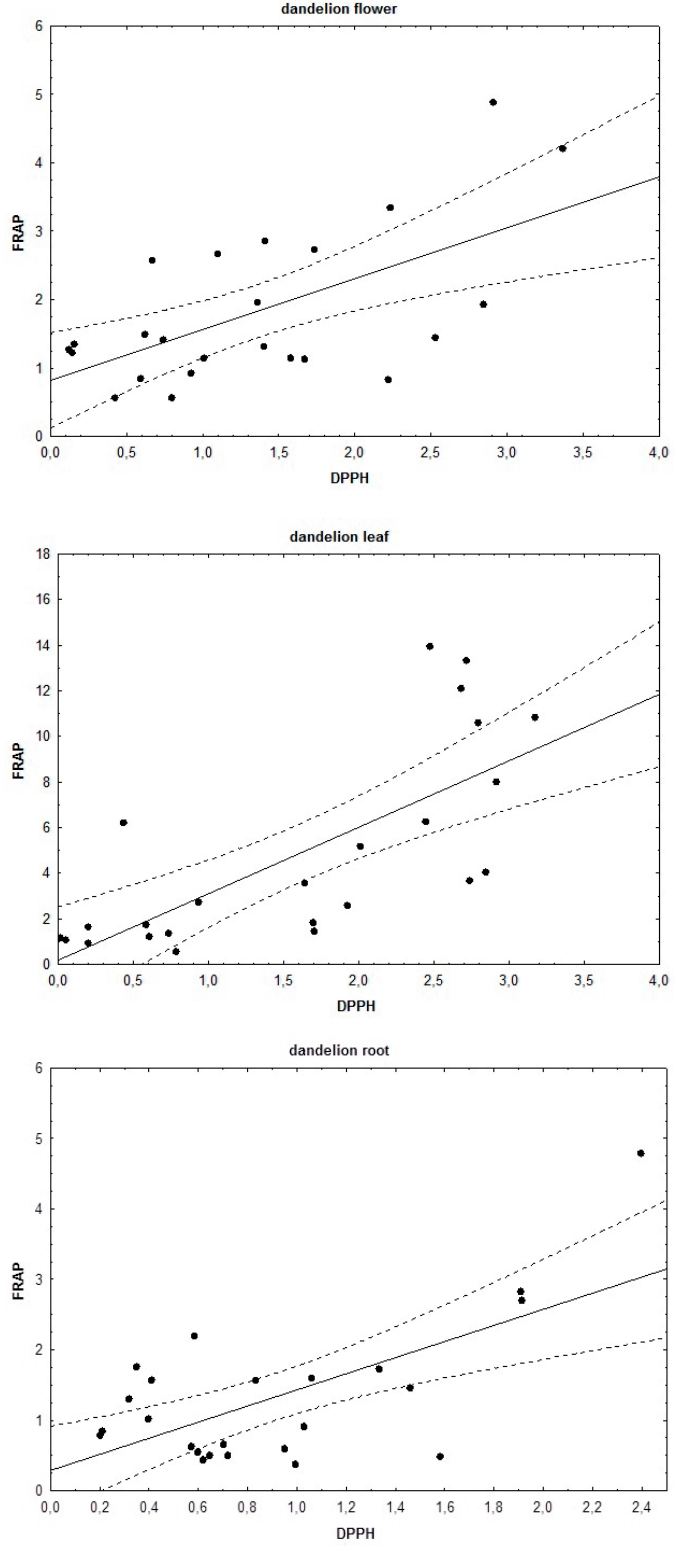

FIGURE 2. The relationship between the antioxidant activity assessed with DPPH technique and iron reduction capacity evaluated with FRAP method for the extracts of all dandelion parts

$30 \mathrm{~min}$, and by extracts from dried leaves in the same solvent for 60 min (Fig. 1). In our study, the ability to reduce iron $\mathrm{Fe}^{3+}$ was also determined using the FRAP method. It was found that the most valuable extracts were obtained from dried dandelion leaves in 40\% ethanol, regardless of extraction time (Tab. 2).

Many reports proved a therapeutic effect of all parts of the dandelion, however, due to the slightly different composition, they may have a variety of therapeutic applications. The root and leaf could be used mainly in liver failure and in gastric hyposecretion. In addition, these raw materials, especially the root, due to inulin content, are often included in herbal mixtures and are used in the early stage of diabetes to decrease blood sugar levels. The dandelion flower is rich in polysaccharides, and this makes it useful as an anti-inflammatory factor [4]. Due to the valuable composition, mainly the content of polyphenolic compounds, this plant has antioxidant activity $[17,18]$. The content of phenolic compounds depends on the part of the plant, with a higher content found in the leaves $[4,19]$. In our study, the antioxidant activity of the extracts of individual parts of the dandelion was different. In most cases, the highest antioxidant activity was found for both fresh and dried leaf extracts, followed by the flower, and the lowest potential was found for root extracts (Fig. 1). The antiradical activity of various dandelion parts was also observed by others, who studied leaf $[3,18,19,20]$, root $[17$, 21], flower [17, 22], stalk [17, 20, 23], as well as fruit extracts [24].

In our study, the antioxidant activity of the dandelion extracts depended on the solvent used for extraction as well as its concentration, i.e. the water content. The antioxidant potential of the aqueous extracts of leaves and flowers was lower compared to ethanolic, particularly with those prepared in $40 \%$ and $70 \%$ alcohol to be of the highest potential. Similar results were obtained by Ivanov, who observed a higher antioxidant activity of dandelion leaves extracts prepared in $50 \%$ ethanol determined by DPPH and FRAP methods compared to extracts in undiluted ethanol. In addition, the samples extracted with diluted alcohol contained the largest amount of chicoric acid, one of the most important active compounds found in dandelion leaves [19]. Tsai et al. observed the highest content of chicoric acid in Echinacea purpurea L. flower extracts prepared in 50\% ethyl alcohol, this plant is also characterized by a high content of this valuable ingredient. The authors applied as extractant, water and $25 \%, 50 \%, 75 \%$ and $95 \%$ ethanol [25]. Chicoric acid is one of the main phenolic compounds to be responsible for the high antioxidant activity of Echinacea purpurea, so, probably diluted ethanol is a better extractant compared to water and undiluted ethanol [26]. Ghaima et al. demonstrated a 44\% inhibition of lipid peroxidation by dandelion dry leaf extracts using 95\% ethyl acetate as extractant [18]. Similar results were obtained by Sengul et al. They observed an antioxidative potential of $43 \%$ for methanolic extracts of dandelion stems [23].

It should be added that dandelion is often administered orally as alcoholic and aqueous extracts. In our study, an attempt was made to assess the antioxidant activity of both ethanolic and aqueous extracts of this plant in order to evaluate which solvent is most preferable as an extractant. It was found that ethanolic extracts were characterized by a much higher antioxidant potential in most cases. Choi et al. applied dandelion root and leaf in dietotherapy as an antiatherosclerotic raw material to protect cells from oxidative stress [27]. Rabbits were fed on a high-cholesterol diet containing $1 \%$ dandelion leaf or root for 4 weeks. The treatment with dandelion led to positive antioxidant and hypolipidemic effects. Due to its antioxidative potential it may prevents endothelial cell injury caused by oxygen-radical action [27]. Root aqueous extracts can play a significant role as hepatoprotective agents in alcoholic liver damage. In an in vivo study by You et al., an aqueous dandelion root extract was administered to 8-week old mice. The animal diet included ethanol as a potential liverdamaging factor. An intake of this compound is connected with oxidative stress via, among others, the production of reactive oxygen species. As a result, in the group of animals with dietary supplementation of dandelion aqueous extracts, a hepatoprotective effect was demonstrated by a significant reduction of blood 
aspartate and alanine aminotransferases, alkaline phosphatase and lactate dehydrogenase activity [28]. The main component of the root is inulin (40-50\%), with probiotic, antidiabetic and anti-sclerotic activity [29, 30]. In our study a lower antioxidant activity compared to the leaves and flowers was observed. This may be partly due to the different chemical composition of these parts of the plant. However, it should be taken into account that the plants for this study were harvested at the beginning of May, during flowering, while the highest content of inulin, a potential antioxidant in the root, could be observed in July [29]. In addition, a high content of flavonoids, i.e. substances with antiradical activity, was found in the leaf and flower extracts, which may explain the high antioxidant activity of these plant organs $[26,31]$.

\section{CONCLUSIONS}

1. The extracts of the individual dandelion parts were characterized by different antioxidant activities, determined by DPPH and FRAP. In the majority of cases, the leaf and flower ethanolic extracts were characterized by a higher antioxidant potential.

2. The extracts of dried flower in $70 \%$ ethanol for $30 \mathrm{~min}$ were the most valuable products taking into account antioxidant activity.

3. Due to its properties, the dandelion could be considered a valuable raw material to be applied in cosmetics and pharmaceuticals.

\section{REFERENCES}

1. Hu Ch. Taraxacum: Phytochemistry and health benefits. Chinese Herbal Med 2018;10:353-61.

2. Wirngo FE, Lambert MN, Jeppesen PB. The physiological effects of dandelion (Taraxacum officinale) in type 2 diabetes. Rev Diabet Stud 2016;13(23):113-31.

3. Garcia-Carrasco B, Fernandez-Dacosta R, Dávalos A, Ordovás JM, Rodriguez-Casado A. In vitro hypolipidemic and antioxidant effects of leaf and root extracts of Taraxacum officinale. Med Sci (Basel) 2015;3(2):38-54.

4. Lis B, Grabek-Lejko D. Mniszek lekarski (Taraxacum officinale) - potencjalne właściwości prozdrowotne. Nauka Przyr Technol 2016;10(3):1-15.

5. Saratale RG, Benelli G, Kumar G, Kim DS, Saratale GD. Bio-fabrication of silver nanoparticles using the leaf extract of an ancient herbal medicine, dandelion (Taraxacum officinale), evaluation of their antioxidant, anticancer potential, and antimicrobial activity against phytopathogens. Environ Sci Pollut Res Int 2018;25(11):10392-406. doi:10.1007/s11356-017-9581-5.

6. Martinez M, Poirrier P, Chamy R, Prüfer D, Schulze-Gronover C, Jorquera $\mathrm{L}$, et al. Taraxacum officinale and related species - An ethnopharmacological review and its potential as a commercial medicinal plant. J Ethnopharmacol 2015;169:244-62.

7. Cai L, Wan D, Yi F, Luan L. Purification, preliminary characterization and hepatoprotective effects of polysaccharides from dandelion root. Molecules 2017;22(9). pii: E1409. doi: 10.3390/molecules22091409.

8. Budny A, Kupczyński R, Sobolewska S, Korczyński M, Zawadzki W. Samolecznictwo i ziołolecznictwo w profilaktyce i leczeniu zwierząt gospodarskich. Acta Sci Pol Med Vet 2012;11(1):5-24.

9. Jędrejek D, Kontek B, Lis B, Stochmal A, Olas B. Evaluation of antioxidant activity of phenolic fractions from the leaves and petals of dandelion in human plasma treated with $\mathrm{H}_{2} \mathrm{O}_{2}$ and $\mathrm{H}_{2} \mathrm{O}_{2} / \mathrm{Fe}$. Chem Biol Interact 2017;262:29-37.
10. Sack MN, Fyhrquist FY, Saijonmaa OJ, Fuster V, Kovacic JC. Basic biology of oxidative stress and the cardiovascular system: Part 1 of a 3-part series. J Am Coll Cardiol 2017;70(2):196-211.

11. Saed GM, Diamond MP, Fletcher NM. Updates of the role of oxidative stress in the pathogenesis of ovarian cancer. Gynecol Oncol 2017;145(3):595-602.

12. Faria A, Persaud SJ. Cardiac oxidative stress in diabetes: mechanisms and therapeutic potential. Pharmacol Ther 2017;172:50-62.

13. Salim S. Oxidative stress and psychological disorders. Curr Neuropharmacol 2014;12(2):140-7.

14. Muzykiewicz A, Zielonka-Brzezicka J, Klimowicz A, Florkowska K. Jarząb pospolity (Sorbus aucuparia L.) jako źródło składników o potencjalnym działaniu antyoksydacyjnym - porównanie właściwości przeciwutleniających ekstraktów z liści, kwiatów i owoców. Probl Hig Epidemiol 2017;98(2):125-32.

15. Zielonka-Brzezicka J, Nowak A, Zielińska M, Klimowicz A. Porównanie właściwości przeciwutleniających wybranych części maliny właściwej (Rubus idaeus) i jeżyny europejskiej (Rubus fruticosus). Pomeranian J Life Sci 2016;62(4):52-9. doi: 10.21164/pomjlifesci.269.

16. Nowak A, Zielonka-Brzezicka J, Pechaiko D, Tkacz M, Klimowicz A. Ocena właściwości antyoksydacyjnej liści Ginkgo biloba L. po zakończeniu wegetacji. Pomeranian J Life Sci 2017;63(1):24-30. doi: 10.21164/pomjlifesci.222.

17. Amin MM, Sawhney SS, Jassal MS. Comparative antioxidant power determination of Taraxacum officinale by FRAP and DPPH method. Pharm Anal Acta 2013;4(3):1-5.

18. Ghaima KK, Hashim NM, Ali SA. Antibacterial and antioxidant activities of ethyl acetate extract of nettle (Urtica dioica) and dandelion (Taraxacum officinale). J Appl Pharm Sci 2013;3(5):96-9.

19. Ivanov IG. Polyphenols content and antioxidant activities of Taraxacum officinale F.H. Wigg (Dandelion) leaves. Int J Pharmacogn Phytochem Res 2014-15;6(4):889-93.

20. Xie P, Huan L, Zhang C, Ding S, Deng Y, Wang X. Skin-care effect of dandelion leaf and stem extract: Antioxidant properties, tyrosinase inhibitory and molecular docking simulations. Industrial Crop Prod 2018;111:238-46.

21. Kenny O, Smyth TJ, Hewage CM, Brunton NP. Antioxidant properties and quantitative UPLC-MS/MS analysis of phenolic compounds in dandelion (Taraxacum officinale) root extracts. Free Rad Antiox 2014;4(1):55-61.

22. Hu C, Kitts DD. Dandelion (Taraxacum officinale) flower extract suppresses both reactive oxygen species and nitric oxide and prevents lipid oxidation in vitro. Phytomedicine 2005;12(8):588-97.

23. Sengul M, Yildiz H, Gungor N, Cetin B, Eser Z, Ercisli S. Total phenolic content, antioxidant and antimicrobial activities of some medicinal plants. Pak J Pharm Sci 2009;22(1):102-6.

24. Colle D, Arantes LP, Rauber R, de Mattos SEC, Rocha JBTD, Nogueira CW, et al. Antioxidant properties of Taraxacum officinale fruit extract are involved in the protective effect against cellular death induced by sodium nitroprusside in brain of rats. Pharm Biol 2012;50(7):883-91.

25. Tsai YL, Chiou SY, Chan KC, Sung JM, Lin SD. Caffeic acid derivatives, total phenols, antioxidant and antimutagenic activities of Echinacea purpurea flower extracts. Food Sci Techno 2012;46:169-76.

26. Gawlik-Dziki U. Fenolokwasy jako bioaktywne składniki żywności. Żywn Nauka Technol Jakość 2004;4(41):29-40.

27. Choi UK, Lee OH, Yim JH, Cho CW, Rhee YK, Lim SI, et al. Hypolipidemic and antioxidant effects of dandelion (Taraxacum officinale) root and leaf on cholesterol-fed rabbits. Int J Mol Sci 2010;11(1):67-78.

28. You Y, Yoo S, Yoon HG, Park J, Lee YH, Kim S, et al. In vitro and in vivo hepatoprotective effects of the aqueous extract from Taraxacum officinale (dandelion) root against alcohol-induced oxidative stress. Food Chem Toxicol 2010;48(6):1632-7.

29. Stolze A, Wanke A, van Deenen N, Geyer R, Prüfer D, Schulze Gronover C. Development of rubber-enriched dandelion varieties by metabolic engineering of the inulin pathway. Plant Biotechnol J 2017;15(6):740-53.

30. Nowak A, Klimowicz A, Bielecka-Grzela S, Piechota M. Inulina - cenny składnik żywieniowy. Ann Acad Med Stetin 2012;58(1):62-5.

31. Florkowska K, Duchnik W, Muzykiewicz A, Zielonka-Brzezicka J, Klimowicz A. Flawonoidy w profilaktyce i leczeniu miażdżycy. Probl Hig Epidemiol 2017;98(3):217-25. 